LWSA

Local Wisdom, Social, and Arts

PAPER - OPEN ACCESS

\title{
Legal Standing Yayasan sebagai Badan Hukum
}

\author{
Author \\ : Sunarmi Sunarmi \\ DOI \\ : 10.32734/lwsa.v1i1.174 \\ Electronic ISSN \\ : 2654-7058 \\ Print ISSN \\ : 2654-7066 \\ Volume 1 Issue 1 - 2018 TALENTA Conference Series: Local Wisdom, Social and Arts
}

\section{(c) $(1) \Theta$}

This work is licensed under a Creative Commons Attribution-NoDerivatives 4.0 International License.

Published under licence by TALENTA Publisher, Universitas Sumatera Utara
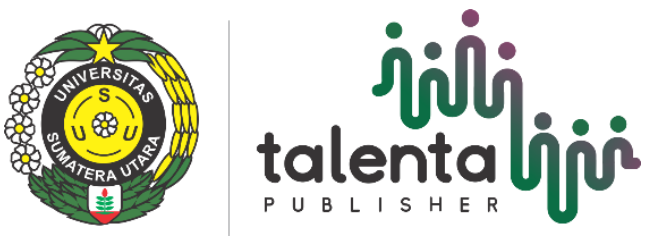


\title{
Legal Standing Yayasan sebagai Badan Hukum
}

\author{
Sunarmi ${ }^{\text {a }}$ \\ ${ }^{a}$ Fakultas Hukum, Universitas Sumatera Utara, Medan-20155
}

sunarmi15@yahoo.co.id

\begin{abstract}
Abstrak
Dalam Pasal 1 angka 1 UU No. 16 Tahun 2001 tentang Yayasan disebutkan bahwa yayasan adalah badan hukum (rechtspersoon, legal entity) yang terdiri atas kekayaan yang dipisahkan dan diperuntukkan untuk mencapai tujuan tertentu di bidang sosial, keagamaan, dan kemanusiaan, yang tidak mempunyai anggota. Sebagai badan hukum maka yayasan memiliki harta kekayaan tersendiri yang terpisah dari harta kekayaan organ yayasan yaitu pembina, pengurus dan pengawas. Apabila korporasi dalam bentuk Perseroan Terbatas, pemiliknya adalah para pemegang saham, maka pemiliki yayasan itu bukanlah pendiri yayasan. Pemilik yayasan adalah tujuan yayasan itu sendiri, sehingga apabila terjadi dugaan penyimpangan terhadap aset yayasan, permasalahannya adalah apakah masyarakat memiliki kedudukan hukum (legal standing) untuk meyampaikan laporan kepada kepolisian terhadap organ yayasan yang diindikasikan melakukan perbuatan melawan hukum yang merugikan yayasan, siapakah yang memiliki kewenangan untuk melakukan pemeriksaan yayasan apabila terdapat dugaan penyimpangan terhadap aset yayasan dan siapakah yang bertanggung jawab terhadap terjadinya penyimpangan aset yayasan.

Permasalahan di atas penting untuk dikemukakan melihat banyaknya laporan dari masyarakat anggota suatu perkumpulan yayasan yang melaporkan terjadinya perbuatan melawan hukum yang dilakukan oleh organ yayasan, sementara masyarakat dan penegak hukum masih memiliki tafsir yang berbeda terhadap pemahaman bahwa yayasan adalah milik masyarakat. Ada yang berpendapat bahwa yayasan adalah badan hukum publik dengan mengingat tujuan yayasan adalah sosial, keagamaan dan kemanusiaan sehingga yayasan bertujuan untuk melayani kepentingan umum, dengan demikian konsekwensinya adalah masyakat memiliki kewenangan untuk menyampaikan laporan terjadinya dugaan penyelewengan terhadap aset yayasan. Di pihak lain ada yang berpendapat bahwa yayasan adalah badan hukum privat karena didirikan oleh orang perorangan sebagaimana ditentukan dalam Pasal 9 Undang -Undang No. 16 Tahun 2001. Tulisan ini bertujuan untuk mengkaji secara normatif siapakah yang memiliki legal standing untuk menyampaikan laporan terjadinya perbuatan melawan hukum dalam suatu yayasan dengan menggunakan pendekatan normatif Dari hasil penelitian diketahui bahwa ditinjau dari segi Undang-Undang No. 16 Tahun 2001 tentang Yayasan, pengurus yayasan memiliki legal standing untuk mewakili kepentingan yayasan baik di dalam maupun di luar pengadilan (Pasal 35 ayat (1). Apabila pengurus terindikasi melakukan perbuatan melawan hukum yang mengakibatkan kerugian terhadap yayasan maka pengurus tersebut tidak berwenang mewakili kepentingan yayasan, yang berwenang mewakili kepentingan yayasan adalah pihak sebagaimana diatur dalam Anggaran Dasar (Pasal 36). Apabila terdapat dugaan terjadinya penyimpangan terhadap harta kekayaan yayasan maka Bab VIII tentang Pemeriksaan Terhadap Yayasan menentukan bahwa pihak ketiga yang berkepentingan dapat mengajukan permohonan tertulis disertai alasannya agar pengadilan mengeluarkan penetapan untuk melakukan pemeriksaan terhadap yayasan. Hal ini dilakukan sebagai bentuk pengawasan publik terhadap yayasan yang diduga melakukan perbuatan yang bertentangan dengan Undang-undang, Anggaran Dasar, atau merugikan kepentingan umum. Apabila penyimpangan terhadap aset yayasan tersebut dilakukan oleh organ yayasan maka yang bertanggung jawab adalah organ yayasan itu sendiri.
\end{abstract}

Kata kunci : Legal standing; yayasan, badan hukum. 


\section{Pendahuluan}

UU No. 16 Tahun 2001 tentang Yayasan berlaku efektif pada Tahun 2002 dan kemudian diamandeman dengan keluarnya UU No. 28 Tahun 2004 dan selanjutnya untuk melaksanakan Undang- undang tersebut dikeluarkanlah PP No. 68 tahun 2004 dan PP No, 2 Tahun 2013. Lahirnya UU Yayasan tersebut diharapkan dapat menjadi pedoman dan arah yang jelas tentang berbagai hal yang berkaitan dengan Yayasan. Pada prinsipnya tujuan diundangkannya UU Yayasan tersebut adalah untuk lebih menjamin kepastian dan ketertiban hukum serta memberikan dasar yang pasti sebagai landasan berpijak mengenai kedudukan Yayasan demi kepentingan sosial, keagamaan dan kemanusiaan.

Dalam Pasal 1 angka 1 UU No. 16 Tahun 2001 tentang Yayasan disebutkan bahwa Yayasan adalah badan hukum yang terdiri atas kekayaan yang dipisahkan dan diperuntukkan untuk mencapai tujuan tertentu di bidang sosial, keagamaan, dan kemanusiaan, yang tidak mempunyai anggota. Pasal 1 angka 1 UU No. 16 Tahun 2001 tersebut memberikan penegasan bahwa yayasan adalah badan hukum (recht persoon). Penegasan ini penting sebab selama ini penegasan bahwa yayasan adalah badan hukum hanya didasarkan pada hukum kebiasaan, yurisprudensi dan doktrin, sehingga ada dua anggapan yang mengatakan bahwa yayasan adalah badan hukum dan yayasan bukan badan hukum. Sebelum keluarnya UU yayasan ini, maka penegasan yayasan sebagai badan hukum dapat dilihat dalam Yurisprudensi Mahkamah Agung sebagaimana termaktub dalam Putusan Mahkamah Agung tanggal 27 Juni 1973 Nomor 124K/Sip/1973, Mahkamah Agung telah membenarkan putusan judex factie sebagai berikut :

a. Bahwa Yayasan Dana Pensiun H.M.B, didirikan di Jakarta dengan nama - Stichting Pensiunfonds H.M.B, Indonesie" dan bertujuan untuk menjamin keuangan para anggotanya.

b. Bahwa para anggotanya ialah pegawai NV.H.M.B

c. Bahwa yayasan tersebut mempunyai pengurus sendiri terlepas dari NV.H.M.B, dimana ketua dan bendahara dipilih oleh Direksi NV.H.M.B.

d. Bahwa pengurus yayasan tersebut mewakili yayasan di dalam dan di luar pengadilan.

e. Bahwa yayasan tersebut mempunyai harta sendiri, antara lain harta benda hibah dari NV.H.M.B (akte hibah).

f. Bahwa dengan demikian yayasan tersebut merupakan suatu badan hukum.

Sebagai badan hukum maka yayasan merupakan subyek hukum yang mandiri yang memiliki harta kekayaan yang terpisah dari harta kekayaan pendirinya (separate legal entity). Kekayaan yang dipisahkan adalah dipisahkan antara kekayaan Yayasan dengan kekayaan para pendirinya. Ini merupakan syarat mutlak untuk mendirikan Yayasan yakni kekayaan harus dipisahkan, tanpa persyaratan tersebut maka yayasan hanya akan merupakan suatu perkumpulan biasa sebagaimana diatur dalam Pasal 1653 KUH Perdata.

Yayasan sebagai badan hukum dalam menjalankan aktivitasnya dilakukan melalui organ yayasan. Pasal 2 UU No. 16 Tahun 2001 menyebutkan bahwa Yayasan mempunyai organ yang terdiri atas pembina, pengurus dan pengawas. Ketentuan tentang organ yayasan ini memberikan penegasan tentang pihak-pihak yang dapat mewakili yayasan dalam menjalankan aktivitasnya sebagai lembaga sosial. Hal ini penting untuk mengatasi terjadinya konflik yang yang sering muncul dalam pengelolaan yayasan antara lain dalam bentuk:

a. Konflik antara badan pendiri;

b. Konflik tentang tujuan yang menyimpang;

c. Konflik masalah keuangan;

d. Konflik tentang kepemilikan; dan

e. Konflik masalah kewenangan dan tanggung jawab.

Konflik di atas muncul karena tidak adanya undang-undang yang menjadi pedoman yang tegas dalam penegelolaan yayasan sehingga yayasan dikelola secara bebas. Akibatnya adalah tidak terjaminnya kepastian hukum, karena adanya perbedaan dalam praktek serta sulitnya pemerintah maupun masyarakat luas mengontrol pengelolaan Yayasan. Kondisi ini berjalan bertahun tahun bahkan sejak jaman kolonial Belanda. Berbagai penyimpangan dalam pengelolaan yayasan banyak terjadi dan hal ini berjalan sangat lama, sehingga ketika pemerintah mengeluarkan regulasi untuk mengatur tentang yayasan banyak pihak yang tidak siap dengan perubahan tersebut.

Permasalahan lain yang muncul antara lain masih banyak yayasan yang di indikasikan melakukan penyimpangan terhadap dana-dana yang dikelola oleh yayasan. Dalam hal ini masyarakat yang berkepentingan melaporkan dugaan penyimpangan tersebut kepada pihak yang berwenang seperti kepolisian. Permasalahannya adalah apakah masyarakat memiliki legal standing untuk menyampaikan dugaan terjadinya penyelewengan tersebut. Apabila masyarakat tidak memiliki legal standing, siapakah yang berwenang menyampaikan laporan tersebut dan apabila 
pelaku dugaan penyelewengan tersebut adalah organ yayasan itu sendiri, bagaimanakah pengawasan yang dilakukan terhadap yayasan tersebut. Uraian diatas menarik untuk dikaji mengingat pada satu sisi yayasan adalah lembaga sosial yang menerima dana dari sumbangan atau bantuan yang tidak mengikat baik dari negara, masyarakat dan lembaga asing, wakaf, hibah dan hibah wasiat. Yayasan juga tidak punya anggota dan di sisi lain yayasan adalah badan hukum yang memiliki harta kekayaan yang terpisah dari harta kekayaan organ- organ yayasan. Kajian dalam tulisan ini didasarkan secara normatif dengan mengacu pada peraturan perundang-undangan yang berlaku dan berbagai literatur di bidang hukum.

\section{Permasalahan.}

Adapun permasalahan yang dikemukakan dalam tulisan ini adalah :

1. Siapakah yang memiliki kedudukan hukum (legal standing) untuk meyampaikan laporan terhadap yayasan yang diindikasikan melakukan perbuatan melawan hukum yang merugikan yayasan,

2. Siapakah yang memiliki kewenangan untuk melakukan pemeriksaan yayasan apabila terdapat dugaan penyimpangan terhadap aset yayasan dan

3. Siapakah yang bertanggung jawab terhadap terjadinya penyimpangan aset yayasan.

\section{Pembahasan}

1. Legal standing yayasan sebagai badan hukum

Yayasan adalah badan hukum yang mandiri (legal entity). Sebagai badan hukum yang mandiri maka yayasan adalah subjek hukum yang memiliki hak dan kewajiban, serta harta kekayaan sendiri terpisah dari organ-organnya.

Ali Ridho menyebutkan syarat-syarat badan hukum yaitu:

a. adanya harta kekayaan yang terpisah;

b. mempunyai tujuan tertentu;

c. mempunyai kepentingan sendiri;

d. mempunyai organisasi yang teratur.

Dalam menjalankan kegiatannya, yayasan memiliki organ-organ seperti pembina, pengurus dan pengawas. Hal ini secara tegas disebutkan dalam UU No. 16 Tahun 2001 mulai dari Pasal 28 sampai dengan Pasal 47. Uraian pasalpasal tersebut adalah sebagai berikut :

Pembina adalah organ Yayasan yang memiliki kekuasan tertinggi berupa kewenangan yang tidak diserahkan kepada Pengurus atau Pengawas oleh UU ini atau Anggaran Dasar. Kewenangan Pembina meliputi tersebut meliputi: a. Keputusan mengenai perubahan Anggaran Dasar;

b. Pengangkatan dan pemberhentian anggota Pengurus dan anggota Pengawas;

c. Penetapan kebijakan umum Yayasan berdasarkan Anggaran Dasar Yayasan;

d. Pengesahan program kerja dan rancangan anggaran tahunan Yayasan; dan

e. Penetapan keputusan mengenai penggabungan atau pembubaran Yayasan (Pasal 28)

Anggota Pembina tidak boleh merangkap menjadi anggota Pengurus dan/atau anggota Pengawas (Pasal 29) Selanjutnya ketentuan Pasal 31 sampai dengan 39 mengatur tentang Pengurus yayasan. Disebutkan bahwa Pengurus adalah organ Yayasan yang melaksanakan kepengurusan Yayasan yang bertanggung jawab penuh atas kepengurusan Yayasan untuk kepentingan dan tujuan Yayasan serta berhak mewakili Yayasan baik di dalam maupun di luar Pengadilan. Setiap Pengurus menjalankan tugas dengan itikad baik, dan penuh tanggung jawab untuk kepentingan dan tujuan Yayasan. Dalam menjalankan tugas, Pengurus dapat mengangkat dan memberhentikan pelaksana kegiatan Yayasan. Ketentuan mengenai syarat dan tata cara pengangkatan dan pemberhentian pelaksana kegiatan Yayasan diatur dalam Anggaran Dasar Yayasan. Setiap Pengurus bertanggung jawab penuh secara pribadi apabila yang bersangkutan dalam menjalankan tugasnya tidak sesuai dengan ketentuan Anggaran Dasar, yang mengakibatkan kerugian Yayasan atau pihak ketiga.

Ketentuan Pasal 40 mengatur tentang Pengawas yayasan yaitu bahwa Pengawas adalah organ Yayasan yang bertugas melakukan pengawasan serta memberi nasihat kepada Pengurus dalam menjalankan kegiatan Yayasan. Yayasan memiliki Pengawas sekurang-kurangnya 1 orang Pengawas yang wewenang, tugas, dan tanggung jawabnya diatur dalam Anggaran Dasar. Yang dapat diangkat menjadi Pengawas adalah orang perseorangan yang mampu 
melakukan perbuatan hukum. Pengawas tidak boleh merangkap sebagai Pembina atau Pengurus. Pengawas wajib dengan itikad baik dan penuh tanggung jawab menjalankan tugas untuk kepentingan Yayasan.

Sebagai badan hukum maka pelaksanaan kepentingan dan tujuan yayasan diwakili oleh pengurus yayasan. Hal ini ditegaskan dalam Pasal 35 ayat (1) yang menentukan bahwa pengurus yayasan bertanggung jawab penuh atas kepengurusan yayasan untuk kepentingan dan tujuan yayasan serta berhak mewakili yayasan baik di dalam maupun di luar pengadilan.

Dari ketentuan Pasal 35 ayat (1) ini secara tegas dapat diketahui bahwa apabila terdapat indikasi yang merugikan harta kekayaan yayasan maka yang berwenang untuk mengajukan laporan kepada kepolisian adalah pengurus yayasan. Ketentuan ini sejalan dengan konstruksi hukum bahwa yayasan adalah badan hukum yang mandiri yang memiliki harta kekayaan tersendiri yang terpisah dengan harta kekayaan organ-organ yayasan. Apabila terjadi dugaan penyalah gunaan aset yayasan maka yang dirugikan adalah yayasan itu sendiri, sehingga menjadi kewajiban pengurus melaporkan dugaan tersebut kepada pihak yang yang berwenang atau mengajukan tuntutan ganti kerugian. Dalam hal, apabila yang diduga melakukan penyalahgunaan aset yang merugikan yayasan adalah pengurus yayasan maka ketentuan Pasal Pasal 36 secara tegas menyebutkan :

1) Anggota Pengurus tidak berwenang mewakili Yayasan apabila :

a) terjadi perkara di depan pengadilan antara Yayasan dengan anggota Pengurus yang bersangkutan; atau

b) anggota Pengurus yang bersangkutan mempunyai kepentingan yang bertentangan dengan kepentingan Yayasan.

2) Dalam hal terdapat keadaan sebagaimana dimaksud dalam ayat (1), yang berhak mewakili Yayasan ditetapkan dalam Anggaran Dasar.

Dari uraian pasal-pasal di atas diketahui bahwa yang memiliki legal standing dalam suatu yayasan untuk melaporkan terjadinya dugaan penyalah gunaan terhadap aset yayasan atau mengajukan tuntutan ganti rugi terhadap pelaku perbuatan melawan hukum yayasan adalah pengurus yayasan, bukan masyarakat secara umum. Apabila masyarakat mengetahui terjadinya dugaan penyalah gunaan aset yayasan maka UU No. 16 Tahun 2001 menyediakan mekanisme pemeriksaan terhadap yayasan melalui mekanisme pemeriksaan yang diatur mulai dari Pasal 53 sampai dengan Pasal 56. Hal ini merupakan mekanisme pengawasan publik terhadap yayasan yang diduga melakukan perbuatan yang bertentangan dengan Undang-undang, Anggaran Dasar, atau merugikan kepentingan umum. selain itu juga UU No. 16 Tahun 2001 mewajibkan pengeloaan yang secara transparan dan akuntabel.

Apabila bertitik tolak dari teori-teori badan hukum tentang kekayaan bertujuan maka jelas bahwa kekayaan bertujuan itu tidak ada pemiliknya. Pendiri bukanlah pemilik yayasan sebab ia telah memisahkan kekayaannya untuk menjadi kekayaan milik badan hukum yayasan, pengurus bukanlah pemilik yayasan karena ia hanya diangkat untuk mengurus yayasan. Pengawas yayasan bukanlah pemilik yayasan karena bertugas untuk mengawasi peneglolaan yayasan. Untuk mengetahui pemilik yayasan maka kita bisa merujuk pada ketentuan Pasal 68 yang mengatur tentang aset yayasan hasil likuidasi. Ketentuan dalam Pasal 68 UU No. 16 Tahun 2001 menyebutkan :

1) Kekayaan sisa hasil likuidasi diserahkan kepada Yayasan lain yangg mempunyai makssd dan tujuan yang sama dengan Yayasan yang bubar.

2) Dalam hal sisa hasil likuidasi tidak diserahkan kepada Yayasan lain yang mempunyai maksud dan tujuan yang sama sebagaimana dimaksud dalam ayat (1), sisa kekayaan tersebut diserahkan kepada Negara dan penggunaannya dilakukan sesuai dengan maksud dan tujuan Yayasan tersebut.

Dari ketentuan tersebut memperlihatkan bahwa kekayaan yayasan adalah milik - tujuan yayasan \| itu sendiri. Pengadilan Alkmaar dalam putusanya tanggal 27 November 1980 (Nederlandse Jurisprudentie 1981 No. 602) tidak mengabulkan perubahan tujuan yayasan yang bermaksud untuk memberi tunjangan kepada kerabat sedarah (ahli waris) dari pendiri yayasan.

\section{Kewenangan untuk melakukan pemeriksaan yayasan apabila terdapat dugaan penyimpangan terhadap} aset yayasan.

Pengelolaan kekayaan dan pelaksanaan kegiatan yayasan dilakukan sepenuhnya oleh pengurus. Dalam mengelola aset yayasan, pengurus wajib melaksanakan prinsip transparansi dan akuntabilitas. Dalam hal ini pengurus wajib membuat laporan tahunan yang disampaikan kepada pembina mengenai keadaan keuangan dan perkembangan 
kegiatan yayasan. Selanjutnya terhadap yayasan yang kekayaannya berasal dari Negara, bantuan luar negeri atau pihak lain, atau memiliki kekayaan dalam jumlah yang ditentukan dalam Undang-undang ini, kekayaannya wajib diaudit oleh akuntan publik dan laporan tahunannya wajib diumumkan dalam surat kabar berbahasa Indonesia.

Walaupun UU No. 16 Tahun 2004 secara tegas menyebutkan kewajiban pengelolaan aset yayasan secara transparan dan akuntabel namun hal ini belum berjalan sepenuhnya. Apabila terdapat dugaan penyimpangan terhadap aset yayasan, UU No. 16 Tahun 2004 tentang yayasan menyediakan mekanisme pemeriksaan yayasan. Ketentuan Pasal 53 menyebutkan :

1) Pemeriksaan terhadap Yayasan untuk mendapatkan data atau keterangan dapat dilakukan dalam hal terdapat dugaan bahwa organ Yayasan :

a. melakukan perbuatan melawan hukum atau bertentangan dengan Anggaran Dasar;

b. lalai dalam melaksanakan tugasnya;

c. melakukan perbuatan yang merugikan Yayasan atau pihak ketiga; atau

d. melakukan perbuatan yang merugikan Negara.

2) Pemeriksaan sebagaimana dimaksud dalam ayat (1) huruf a, huruf b, dan huruf c hanya dapat dilakukan berdasarkan penetapan Pengadilan atas permohonan tertulis pihak ketiga yang berkepentingan disertai alasan.

3) Pemeriksaan sebagaimana dimaksud dalam ayat (1) huruf d dapat dilakukan berdasarkan penetapan Pengadilan atas permintaan Kejaksaan dalam hal mewakili kepentingan umum Pasal 54 menentukan :

1) Pengadilan dapat menolak atau mengabulkan permohonan pemeriksaan sebagaimana dimaksud dalam Pasal 53 ayat (2).

2) Dalam hal Pengadilan mengabulkan permohonan pemeriksaan terhadap Yayasan, Pengadilan mengeluarkan penetapan bagi pemeriksaan dan mengangkat paling banyak 3 (tiga) orang ahli sebagai pemeriksa untuk melakukan pemeriksaan.

3) Pembina, Pengurus, dan Pengawas serta pelaksana kegiatan atau karyawan Yayasan tidak dapat diangkat menjadi pemeriksa sebagaimana dimaksud dalam ayat (2). Pasal 55 menentukan :

1) Pemeriksa berwenang memeriksa semua dokumen dan kekayaan Yayasan untuk kepentingan pemeriksaan.

2) Pembina, Pengurus, Pengawas, dan pelaksana kegiatan serta karyawan Yayasan, wajib memberikan keterangan yang diperlukan untuk pelaksanaan pemeriksaan.

3) Pemeriksa dilarang mengumumkan atau memberitahukan hasil pemeriksaannya kepada pihak lain. Pasal 56 menentukan :

1) Pemeriksa wajib menyampaikan laporan hasil pemeriksaan yang telah dilakukan kepada Ketua Pengadilan di tempat kedudukan Yayasan paling lambat 30 (tiga puluh) hari terhitung sejak tanggal pemeriksaan selesai dilakukan.

2) Ketua Pengadilan memberikan salinan laporan hasil pemeriksaan sebagaimana dimaksud dalam ayat kepada pemohon atau Kejaksaan dan Yayasan yang bersangkutan.

Demikian UU No. 16 Tahun 2004 tentang yayasan menyediakan mekanisme pemeriksaan yayasan. Ketentuan tentang mekanisme pengawasan publik inilah yang belum banyak dipahami masyarakat sehingga dari hasil penelusuran penulis implementasi seperti ini belum dilaksanakan.

3. Pihak yang bertanggung jawab terhadap terjadinya penyimpangan aset yayasan.

Setiap orang dalam organ yayasan tidak bertanggungjawab terhadap perbuatan hukum yang dilakukannya, kecuali apabila terbukti karena kelalaiannya perbuatan tersebut menimbulkan kerugian bagi yayasan atau pihak ketiga. Di dalam UU No. 16 Tahun 2004 tentang Yayasan hanya meletakkan tanggung jawab kepada pengurus dan pengawas. Ada tanggung jawab yang dilakukan secara renteng antara organ dan yayasan, ada pula yang dilakukan secara renteng antar organ, dan ada pula pertanggungjawabannya yang dilakukan secara perorangan.

\section{Kesimpulan dan Saran}

Yayasan adalah Badan Hukum. Sebagai badan hukum maka yayasan memiliki harta kekayaan sendiri yang terpisah dari harta kekayaan organ yayasan. Dalam menjalankan aktivitasnya yayasan memiliki organ yang terdiri atas pembina, pengurus dan pengawas. Pengurus merupakan organ yang menjalankan kepengurusan yayasan dan mewakili 
kepentingan yayasan baik di dalam maupun di luar pengadilan. Ketentuan ini membawa konsekwensi bahwa apabila terjadi dugaan penyalahgunaan aset di dalam yayasan maka yang mewakili kepentingan yayasan atau legal standing untuk melaporkan ke pihak yang berwenang dan mengajukan tuntutan ganti kerugian adalah pengurus yayasan.

Masyarakat umum memiliki kewenangan untuk melakukan pengawasan melalui mekanisme pengawasan publik terhadap yayasan yang diduga melakukan perbuatan yang bertentangan dengan Undang-undang, Anggaran dasar, atau merugikan kepentingan umum. Pengawasan tersebut dilakukan dalam bentuk pemeriksaan terhadap yayasan yang dilakukan oleh ahli berdasarkan penetapan Pengadilan.

Setiap orang dalam organ yayasan tidak bertanggungjawab terhadap perbuatan hukum yang dilakukannya, kecuali apabila terbukti karena kelalaiannya perbuatan tersebut menimbulkan kerugian bagi yayasan atau pihak ketiga. UU No. 16 Tahun 2004 tentang Yayasan hanya meletakkan tanggung jawab kepada pengurus dan pengawas. Ada tanggung jawab yang dilakukan secara renteng antara organ dan yayasan, ada pula yang dilakukan secara renteng antar organ, dan ada pula pertanggungjawabannya yang dilakukan secara perorangan.

Disarankan untuk selalu diadakan sosialisasi terhadap UU No. 16 Tahun 2004 tentang Yayasan karena meskipun UU ini telah berlaku efektif sejak tahun 2002 tetapi masih banyak yang belum memahami sepenuhnya makna Undangundang ini, kesalahan dalam menafsirkan terutama di kalangan penegak hukum dan masyarakat sebagai organ yang menjadi pengelola yayasan.

\section{References}

[1] Ali, Chidir, Badan Hukum, Bandung : PT. Alumni, 1991.

[2] Ais, Chatamarrasjid, Badan Hukum Yayasan, Jakarta : PT. Citra Aditya Bakti, 2002.

[3] Borahima, Anwar, Kedudukan Yayasan di Indonesia, Jakarta : Kencana, 2010.

[4] Undang-undang No. 16 Tahun 2001.

[5] Undang-undang No. 28 Tahun 2004.

[6] PP No. 68 Tahun 2004.

[7] PP No. 2 Tahun 2013. 